\title{
PENENTUAN NILAI EMISIVITAS WARNA MENGGUNAKAN PENERANGAN PADA MINIATUR RUANG BERBENTUK KUBUS
}

\author{
Cariti Dassa Urra \\ caritidassaurra@gmail.com \\ ${ }^{1}$ SMP Alkarim, Kota Bengkulu, Provinsi Bengkulu
}

Received: 15 Juni 2020

Revised: 17 Juni 2020

Accepted:5 Juli 2020

\begin{abstract}
This study using a cuboidal space miniature aims to determine the emissivity values of purple, green, and blue colors. By carrying out eight actions to change the power of the lamp, starting from incandescent lamps of 5 watts, 25 watts, 60 watts, 75 watts, 100 watts and 5 watts, 20 watts, and 25 watts of white TL lamps. Emissivity value can be calculated by comparing the value of the resistance of each color to the value of black resistance. The results show that the emissivity value of purple (purple comet) is 0.91, emissivity of green (going green) is 0.84, and emissivity of blue (true) blue) of 0.77 .
\end{abstract}

\begin{abstract}
Abstrak: Penelitian dengan menggunakan miniature ruang berbentuk kubus ini bertujuan untuk mengetahui nilai emisivitas warna ungu, hijau, dan biru. Dengan melakukan delapan tindakan mengganti daya lampu, dimulai dari lampu pijar 5 watt, 25 watt, 60 watt, 75 watt, 100 watt dan lampu TL putih 5 watt, 20 watt, dan 25 watt. Nilai emisivitas dapat dihitung dengan membandingkan nilai hambatan setiap warna terhadap nilai hambatan warna hitam Hasil penelitian menunjukkan bahwa nilai emisivitas warna ungu (purple comet) sebesar 0,91, emisivitas warna hijau (going green) sebesar 0,84, dan emisivitas warna biru (true blue) sebesar 0,77.
\end{abstract}

Kata kunci: emisivitas, warna

\section{PENDAHULUAN}

Emisivitas ( $\varepsilon$ ) adalah rasio energi yang dipancarkan oleh material tertentu oleh benda hitam (black body) yang ideal pada suhu yang sama (Jin dan liang, 2005). Hal itu merupakan kemampuan suatu benda untuk meradiasikan energi yang diserapnya. Benda hitam sempurna memiliki emisivitas sama dengan $1(\mathrm{e}=1)$ sementara objek sesungguhnya memiliki emisivitas kurang dari satu. Emisivitas adalah satuan yang tidak berdimensi Pada umumnya, semakin kasar dan hitam benda tersebut, emisivitas meningkat mendekati 1.

Penelitian-penelitian tentang pengaruh warna terhadap perpindahan panas telah banyak dilakukan sebelumnya. (Uemoto, 2010) mengatakan bahwa perubahan warna (polos, putih, kuning dan coklat) mempengaruhi perpindahan panas pada atap, dan warna coklat memiliki temperatur luar paling tinggi diantara warna-warna tersebut. Pada eksperimen yang telah dilakukan dia menggunakan lampu sebagai sumber panas. Dan dari hasil eksperimen 
diketahui bahwa warna coklat memiliki temperatur permukaan tertinggi sebesar $81,7^{0} \mathrm{C}$ dibandingkan warna kuning sebesar $69,8^{\circ} \mathrm{C}$ dan warna putih sebesar $57^{\circ} \mathrm{C}$.

Suatu penerangan diperlukan oleh manusia untuk mengenali suatu objek secara visual. Pencahayaan yang baik memungkinkan orang dapat melihat objek-objek yang dikerjakannya secara jelas dan cepat. Hampir kebanyakan pengguna energi komersial dan industri peduli penghematan energi dalam sistem penerangan. Seringkali, penghematan energi yang cukup berarti investasi yang minim dan masuk akal. Menerapkan sistem pencahayaan yang efisien sehingga penggunaan listrik bisa lebih hemat dan sangat menguntungkan. Pasalnya, pencahayaan atau penerangan mengkonsumsi kurang lebih 30\% dari total energi dalam suatu bangunan. Maka konsumsi listrik sebuah lampu merupakan faktor utama untuk memilih solusi pencahayaan. Dengan desain pencahayaan yang baik, penghematan energi jelas sangat berarti (Amin, 2011).

Suatu penerangan diperlukan oleh manusia untuk mengenali suatu objek secara visual. Pencahayaan yang baik memungkinkan orang dapat melihat objek-objek yang dikerjakannya secara jelas dan cepat. Hampir kebanyakan pengguna energi komersial dan industri peduli penghematan energi dalam sistem penerangan. Seringkali, penghematan energi yang cukup berarti investasi yang minim dan masuk akal. Menerapkan sistem pencahayaan yang efisien sehingga penggunaan listrik bisa lebih hemat dan sangat menguntungkan. Pasalnya, pencahayaan atau penerangan mengkonsumsi kurang lebih 30\% dari total energi dalam suatu bangunan. Maka konsumsi listrik sebuah lampu merupakan faktor utama untuk memilih solusi pencahayaan. Dengan desain pencahayaan yang baik, penghematan energi jelas sangat berarti (Amin, 2011)

Permasalahan sekarang hanya warna hitam dan putih yang diketahui koefisien emisivitasnya, dengan koefisien emisivitas 1 (satu) untuk warna hitam dan 0 (nol) untuk warna putih. Warna-warna selain warna hitam dan putih belum ditemukan literatur yang memuat koefisien emisivitasnya. Di dalam dunia arsitektur, suatu ruangan dituntut untuk memiliki nilai keindahan. Pemberian warna cat pada dinding juga akan memberikan sentuhan yang berbeda pada ruang tersebut, namun di samping itu juga hemat dalam penggunaan energi cahaya. Sehingga pengukuran emisivitas warna lain dirasa perlu dilakukan. 


\section{LANDASAN TEORI}

Emisivitas berhubungan erat dengan dengan radiasi kalor.Joseph Stefan (1853-1893) dan Ludwig Boltzmann (1844-1906) mengemukakan hukum yang disebut dengan Hukum Stefan-Boltzmann yang berbunyi:

"Jumlah energi yang dipancarkan persatuan permukaan suatu benda hitam dalam satuan waktu akan berbanding lurus dengan pangkat empat temperatur termodinamikanya"

Hukum Stefan-Boltzmann ini secara matematis ditulis :

$$
I_{\text {total }}=e \cdot \sigma \cdot T^{4}
$$

Intensitas merupakan daya persatuan luas, maka persamaan (1) dapat ditulis sebagai:

$$
\frac{P}{A}=e \cdot \sigma \cdot T^{4}
$$

Besarnya nilai hambatan masing-masing warna dapat digunakan untuk menentukan nilai emisivitas masing-masing warna tersebut. Dengan menganggap bahwa emisivitas warna hitam adalah 1 dan pada kondisi suhu (T) dan luas daerah (A) yang sama, maka besarnya perbandingan nilai hambatan masing-masing warna dapat dituliskan dalam bentuk :

$$
\frac{k \cdot R_{H}}{k \cdot R_{X}}=\frac{\mathrm{e}_{\mathrm{H}} \sigma T_{H}^{4} A}{\mathrm{e}_{\mathrm{X}} \sigma T_{H}^{4} A}
$$

Perbandingan nilai hambatan ini dapat digunakan untuk menentukan emisivitas masing-masing warna. Nilai emisivitas warna hitam $\left(\mathrm{e}_{\mathrm{H}}\right)=1$, maka persamaan emisivitas dapat dituliskan sebagai berikut :

$$
e_{x}=\frac{R_{x}}{R_{H}}
$$

Keterangan :

$\mathrm{R}_{\mathrm{H}}=$ nilai hambatan warna hitam

$\mathrm{R}_{\mathrm{X}}=$ nilai hambatan warna tertentu

$\mathrm{e}_{\mathrm{H}}=$ emisivitas warna hitam

$\mathrm{e}_{\mathrm{X}}=$ emisivitas warna tertentu

\section{METODE PENELITIAN/EKSPERIMEN}

Penelitian untuk mengukur nilai emisivitas warna ungu (purple comet), hijau (going green), dan biru (true blue). Dengan mengunakan triplek dibuat kotak yang berukuran panjang $70 \mathrm{~cm}$ lebar $70 \mathrm{~cm}$ dan tinggi $70 \mathrm{~cm}$, Miniatur Ruang ini didesain menyerupai sebuah ruangan dengan dinding yang dapat diganti warna.

Puplished at https://ojs.stkippgri-lubuklinggau.ac.id/index.php/SJPIF 


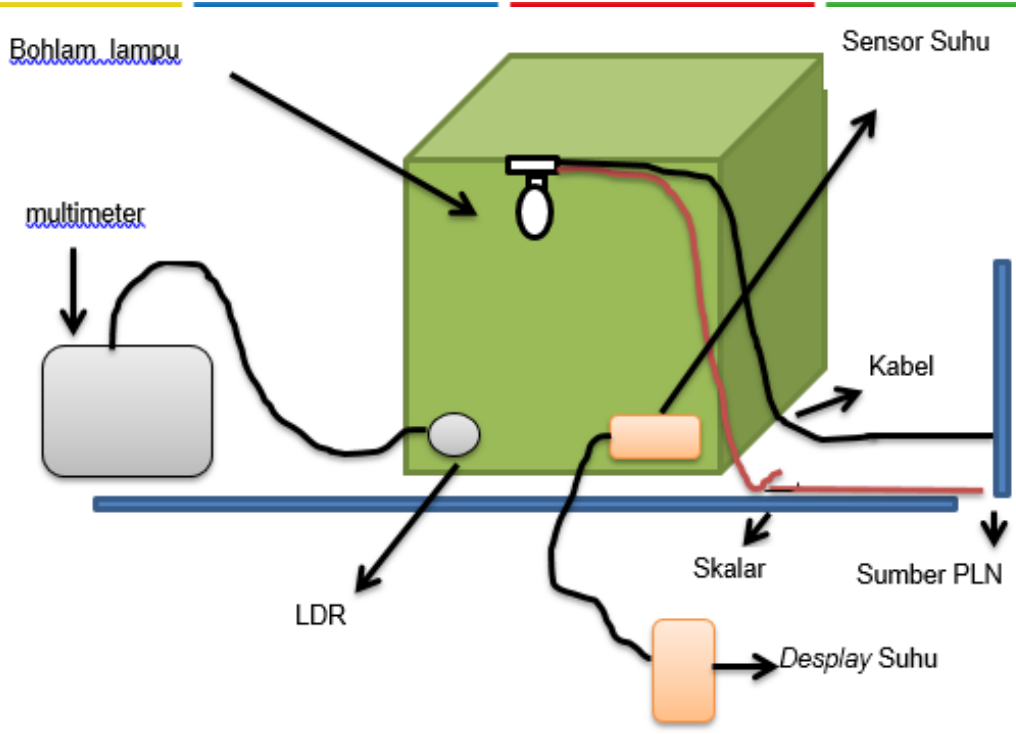

Gambar 1. Penampang Miniatur Ruang Berbentuk Kubus

Dilakukan dengan delapan tindakan mengganti daya lampu. Daya lampu yang digunakan dimulai dari lampu pijar 5 watt, 25 watt, 60 watt, 75 watt, 100 watt dan lampu TL putih 5 watt, 20 watt, dan 25 watt. Nilai emisivitas dapat dihitung dengan membandingkan nilai hambatan setiap warna terhadap nilai hambatan warna hitam. Hambatan setiap warna diukur dengan menggunakan multimeter digital dan multimeter analog sebagai validasi. Hal ini bertujuan agar didapatkan data emisivitas yang akurat.

\section{HASIL DAN PEMBAHASAN}

Pengukuran nilai hambatan yang digunakan untuk menentukan nilai emisivitas menggunakan multimeter digital dan multimeter analog sebagai validasi. Hasil perhitungan nilai emisivitas dari nilai hambatan yang diukur dengan multimeter analog dapat dilihat pada tabel 1 berikut ini :

Tabel 1. Emisivitas Rata-Rata

\begin{tabular}{|c|l|c|r|}
\hline No & \multicolumn{1}{|c|}{ Warna } & $\begin{array}{c}\text { rata- } \\
\text { rata }\end{array}$ & $\begin{array}{c}\text { Standar } \\
\text { Deviasi }\end{array}$ \\
\hline 1 & Ungu (purple comet) & 0,91 & 0,019 \\
\hline 2 & Hijau (going green) & 0,84 & 0,023 \\
\hline 3 & Biru (true blue) & 0,77 & 0,024 \\
\hline
\end{tabular}

Dari data hasil penelitian ini didapat urutan warna berdasarkan nilai emisivitasnya. Urutan warna yang di dapat yaitu : ungu (purple comet), hijau (going green), dan biru (true blue). Urutan tersebut terlihat berdasarkan tingkat gelap dan terang suatu warna. Semakin gelap suatu warna maka semakin besar nilai emisivitasnya, sebaliknya semakin terang suatu Puplished at https://ojs.stkippgri-lubuklinggau.ac.id/index.php/SJPIF 
warna maka semakin kecil nilai emisivitasnya. Hasil penelitian ini sependapat dengan Satwiko (dalam Yohana dkk : 2011) yang menyatakan nilai emisivitas atau absorbsi panas warna gelap lebih besar dibandingkan dengan warna terang sehingga warna gelap cenderung menangkap atau menyimpan panas sedangkan warna terang cenderung memiliki sifat memantulkan panas.

Hasil tersebut didukung oleh Ilminnafik (2015) dalam penelitiannya yang berjudul variasi bahan dan warna atap bangunan untuk menurunkan temperatur ruangan akibat pemanasan global menyatakan warna gelap (merah) cenderung menyerap panas lebih besar dibandingkan warna lebih cerah (abu-abu).

Emisivitas tertinggi pada penelitian ini yaitu warna ungu (purple comet) dengan rata-rata emisivitasnya 0,91 dan standar deviasinya 0,019 . Rata-rata emisivitas warna hijau (going green) sebesar 0,84 dengan standar deviasinya 0,023, sedangkan nilai emisivitas pada literatur (table of total emissivity OMEGASTOPE ) sebesar 0,92 untuk warna green $\mathrm{Cu} 2 \mathrm{O} 3$. Rata-rata emisivitas warna biru (True Blue) sebesar 0,77 dengan standar deviasinya 0,024, sedangkan nilai emisivitas pada literatur (table of total emissivity OMEGASTOPE )sebesar 0,78 untuk blue on al foil.

Berdasarkan hasil penelitian yang telah dilakukan, diperoleh bahwa tiap-tiap warna memiliki nilai emisivitas yang berbeda berdasarkan tingkat kegelapan warnanya. Semakin gelap warna semakin besar nilai emisivitasnya. Begitu pula sebaliknya, semakin terang warnanya semakin kecil nilai emisivitasnya. Besar kecilnya nilai emisivitas menunjukkan kemampuan suatu benda/zat menyerap energi panas dari lingkungannya (Lillesand et al., 2008).

\section{SIMPULAN DAN SARAN}

Berdasarkan hasil penelitian dan pembahasan dapat ditarik kesimpulan bahwa: 1) Nilai emisivitas warna ungu (purple comet) adalah 0,91,emisivitas warna hijau (going green) adalah 0,84, dan emisivitas warna biru (true blue) adalah 0,77. Warna cat yang digunakan sebaiknya ditambah variasinya sehingga memperoleh data yang lebih banyak dan lebih bervariasi

\section{DAFTAR PUSTAKA}

Amin, N. 2011. Optimasi Sistem Pencahayaan dengan Memanfaatkan Cahaya Alami (Studi Kasus Lab. Elektronika dan Mikroprosessor UNTAD). 1(1): 43-50. Diakses 3 Agustus 2016 
Ilminnafik, N., Digdo L.S., Hary S., Ade A M.M. 2015. dan Erfani M. 2015. Variasi bahan dan warna atap bangunan untuk Menurunkan Temperatur Ruangan akibat Pemanasan Global. Seminar Nasional Tahunan Teknik Mesin XIV (SNTTM XIV). Banjarmasin, 7-8 Oktober 2015. Diakses 29 Juni 2016

Jin, M dan Shunlin L. 2005. An Improved Land Surface Emissivity Parameter for Land Surface Models Using Global Remote Sensing Observations. Journal of Climate. 15 Juni 2006. Diakses 23 Agustus 2016

Lillesand, T. M., Kiefer, R. W. \& Chipman, H. W., 2008. Remote Sensing and Image Interpretation. New York : Sixth ed. John Willey \& Son. Diakses 3 Agustus2016

Uemoto, K. L., Neide M.N., dan Vanderley M. John S. 2010. Estimating Thermal Performance of Cool Colored Paints. http://www.elsevier.com/locate/enbuild Diakses 9 Juni 2016

Yohana, E. dan Bayu N. 2011. Perbandingan Stack Effect pada Rumah secara Konveksi Paksa Konveksi Alami Ketika Kondisi Hujan. http://ejournal.undip.ac.id/index.php/rotasi Diakses 3 Agustus 2016 